\title{
Acute Alcohol Poisoning in Bulgarian Adolescents
}

\author{
Bulgar Ergenlerde Akut Alkol Zehirlenmesi
}

\author{
Anelia Milkova LOUKOVA, Evgenia Kirilova STANKOVA \\ Department of Toxicology, Emergency Medicine Institute Pirogov, Sofia, Bulgaria
}

\begin{abstract}
SUMMARY
Objectives

To analyze the medico-social characteristics of acute alcohol poisoning in Bulgarian adolescents.
\end{abstract}

\section{Methods}

We studied patients under 18 years old with acute alcohol poisoning who were hospitalized during the period 2006-2008. Data were retrieved from hospital records. The initial blood ethanol level was measured by thin-layer chromatography. Psychiatric interview and inquiry methods were used.

\section{Results}

The study included 137 adolescents (77 boys, 60 girls) with an average age of $14.91 \pm 1.45$ years. Blood ethanol level was over $2.00 \mathrm{mg} /$ $\mathrm{mL}$ in $40.2 \%$ of cases. Adolescents most often used one type of alcoholic beverage. First alcohol consumption was at the age of 12 years and 10 months (boys), and 13 years (girls). The most frequent reason for alcohol consumption was meeting with friends. It was found that $60 \%$ of the patients were the first-born child in the family. The patients' preferred musical styles varied, and they preferred watching movies, mainly comedies for their free time (64.2\%). The majority of the patients were raised in a family with more than one child (68.6\%) and in non-separated families with both parents present (64\%). The patients' parents predominantly had a secondary-level education (79.7\%) and both parents were employed in $53.3 \%$ of the cases.

\section{Conclusions}

The research concerns the important medico-social problem of alcohol poisoning among adolescents. Health professionals need to be able to identify adolescents who are experiencing difficulties with alcohol. Applying the methods of preventive medicine and clinical toxicology the results of this study indicate a certain social need for further information on the extent and character of the phenomena of adolescent alcohol use and abuse.

Key words: Adolescents; alcohol poisoning; Bulgaria; prevention.

\section{ÖZET \\ Amaç}

Çalışmanın amacı, Bulgar ergenlerinde görülen akut alkol zehirlenmelerinin mediko-sosyal özelliklerini analiz etmektir.

\section{Gereç ve Yöntem}

Çalışma kapsamında 2006-2008 yılları arasında akut alkol zehirlenmesi ile hastaneye yatırılan 18 yaş altındaki hastalarla çalışıldı. Çalışma verileri hastane kayıtlarından elde edildi. Başvuru anındaki kan alkol düzeyi ince tabaka kromatografi yöntemiyle ölçüldü. Hastalarla psikiyatrik görüşme ve bilgi alma yöntemi kullanıldı.

\section{Bulgular}

Çalışmaya 137 ergen (77 erkek, 60 kız) dahil edildi. Hastaların ortalama yaşı $14.91 \pm 1.45$ olarak bulundu. Olguların \%40.2'sinde kan alkol düzeyi $2.00 \mathrm{mg} / \mathrm{mL}$ değerinin üzerinde tespit edildi. Hastaların daha çok tek tür alkollü içecek tükettikleri belirlendi. İlk alkol tüketim yaşı erkeklerde 12 yaş 10 ay, kızlarda 13 yaş olarak saptandı. Alkol tüketimi için en sık bildirilen neden arkadaşlarla buluşmadır. Hastaların hoşlandıkları müzik türleri değişmekle birlikte boş zaman aktivitesi olarak film izlemek (genellikle komedi filmleri) belirtilmiştir (\%64.2). Hastaların \%60'ı ailelerinin ilk çocuklarıdır ancak büyük çoğunluğu ailede başka kardeşlerle (\%68.6), ve anne-babanın bir arada olduğu ortamlarda (\%64) büyümüştür. Hastaların ebeveynleri çoğunlukla ortaokul düzeyinde eğitimlidir (\%79.7) ve her iki ebeveyn de çalışmaktadır (\%53.3).

\section{Sonuç}

Araştırma sonuçları Bulgar ergenler arasında görülen akut alkol zehirlenmelerine ilişkin önemli mediko-sosyal problemleri ortaya koymaktadır. Sağlık profesyonellerinin alkolle sorunları olan ergenleri tespit edebilmeleri gereklidir. Koruyucu tıp ve klinik toksikoloji yöntemleri uygulandığında bu çalışmanın sonuçları, ergenlerde alkol kullanımı ve kötüye kullanımı fenomeninin yaygınlığı ve karakteristik özellikleri hakkında daha fazla bilgi edinmeye ihtiyaç olduğunu göstermektedir. Anahtar sözcükler: Ergen; alkol zehirlenmesi; Bulgaristan; önlem.

Submitted (Geliş tarihi): July 22, 2011 Accepted (Kabul tarihi): September 11, 2011

Correspondence (iletişim): Anelia Milkova Loukova, M.D. Totleben 21, 1606 Sofia, Bulgaria

e-mail (e-posta): aloukova@yahoo.com 


\section{Introduction}

Alcohol is a legal product with toxic and psychotropic effects that may cause increased tolerance and dependency with long-term usage. Early alcohol use increases the risk for chronic alcohol addiction. The social and medical problems of alcohol dependency highlight the issue of rapidly increasing acute alcohol poisoning among children. Summarized data from Bulgarian studies show that part of the proportion of alcohol poisoning in childhood increased from $2.6 \%$ in 1976 to $19.5 \%$ in $2006 . .^{[1-4]}$

Compared to adults, damage due to alcohol intoxication in childhood manifests more rapidly and more severely in cgildhood due to the instability of enzyme systems involved in alcohol metabolism. Acute alcohol poisoning is a transient condition, arising after alcohol intake and leading to disturbances of consciousness, cognitive processes, perceptions, emotions and changes in the course of various behavioral functions and reactions. These disturbances are directly connected to the acute pharmacological effects of alcohol. ${ }^{[5-7]}$

Alcohol is one of the most common contributors to injury, death, and criminal behavior among young people. A variety of effective strategies have been developed to reduce underage drinking. These strategies can be applied in all sectors of society and all stages of thesupply-chain, from producers to consumers. Predictive intervention aims to reinforce protective factors that have been already identified as influencing alcohol consumption in young people. ${ }^{[8-10]}$

The aim of the study is to analyze the medical and social characteristics of acute alcohol poisoning in adolescents with regard to minimizing cases of acute poisoning and prevention of addictive practices.

\section{Materials and Methods}

The study included 137 patients aged between 12 and 17 years, who were admitted to the emergency children's department of a toxicology clinic with acute alcohol poisoning during the period 2006-2008. This is the only department in the country specializing in the treatment of acute poisoning in children up to 18 years of age.

We used the sociological methods (analysis of documents; observation of verbal and non verbal behavior of the subjects) and inquiry method (a 39-item questionnaire, specially created for the study). The questions cover laboratory data; conditions of the acute poisoning; family, home and school environment; heredity; interests, etc.

Blood ethanol level was measured on admission using chemico-toxicological analysis to determine precise blood ethanol concentration (thin-layer chromatography).
Different types of alcohol are preliminary converted to equivalent quantities of ethanol, according to the following standards: vodka, brandy, whisky and other concentrated beverages with alcohol content $40^{\circ}-31.2 \mathrm{~g} / 100 \mathrm{ml}$; wine- 8.8 $\mathrm{g} / 100 \mathrm{ml}$; beer-3.51 g/100 ml.

\section{Statistical Analysis}

Statistical analysis was performed using SPSS (version 16.0.1). The following methods were applied: descriptive analysis; cross-tabulation; analysis of variance (ANOVA); graphic analysis; chi-squared test; Fisher's exact test; Kolmogorov-Smirnov two-sample test; Mann-Whitney (U) test; Student's t-test. A p value $<0.05$ was considered as statistically significant.

\section{Results}

We studied 137 adolescents with acute alcohol poisoning. 77 (56.2\%) were boys and 60 (43.8\%) girls: the average age was $14.91 \pm 1.45$ years. A total of 92 children $(67.2 \%$ of the sample) are recorded with first alcohol poisoning. In terms of blood ethanol level, the largest number of patients (46.7\%) were between $1.30 \mathrm{mg} / \mathrm{ml}-1.99 \mathrm{mg} / \mathrm{ml}$. The preferred type of alcoholic drink was vodka (consumed without mixers). Alcohol is most often consumed in open-air areas (in 56.2\% of the cases), at friends' homes or public premises (16.0-17.0\% each) (Figure 1).

The most common reason for alcohol consumption is meeting with friends (in 93 cases, 68.9\%), followed by birthday parties $(n=28,20.4 \%)$; sadness $(n=7,5.1 \%)$; family celebration $(n=5,3.7 \%)$ or curiosity $(n=4,2.9 \%)$. The estimated average alcohol equivalent leading to poisoning is significantly higher $(p<0.001)$ in boys $(79.68 \mathrm{~g})$ compared with girls $(55.47$ g) (Table 1).

Gender was not significantly related to the age of first alcohol consumption, which was 12 years and 10 months (boys), and 13 years (girls). Early acquaintance with alcohol is typical

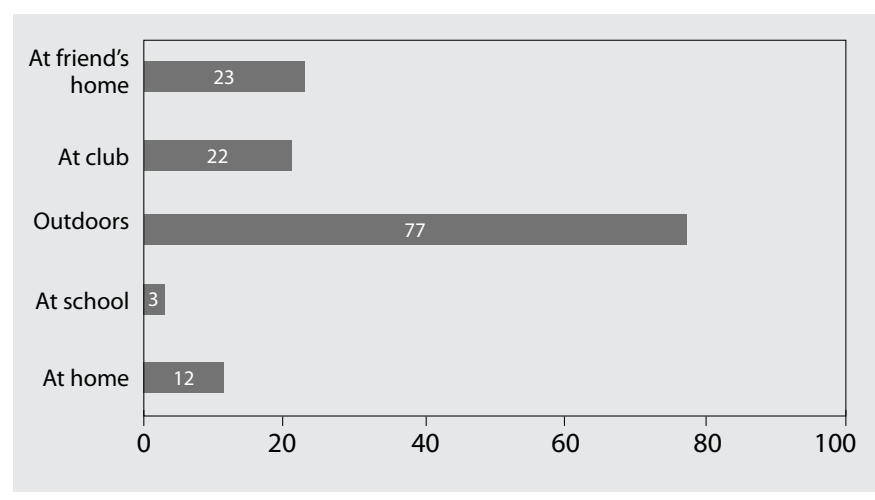

Figure 1. Distribution according to place of alcohol consumption. 
Table 1. Relationship between the amount of consumed alcohol and sex

\begin{tabular}{|c|c|c|c|c|c|c|c|c|c|c|}
\hline \multicolumn{5}{|c|}{ Boys } & \multicolumn{5}{|c|}{ Girls } & \multirow[b]{2}{*}{$P$} \\
\hline$n$ & $\bar{x}$ & SD & Min & Max & $n$ & $\bar{x}$ & SD & Min & Max & \\
\hline 76 & 79.68 & 38.03 & 24.00 & 218.40 & 59 & 55.97 & 30.69 & 8.78 & 156.00 & $<0.001$ \\
\hline
\end{tabular}

for children who come from families with alcohol-addicted parent (nearly $84 \%$ of these children first tried alcohol under the age of 14). The largest proportion of children (nearly $64 \%$ ) live in nuclear families, with both parents present. Children from single-parent households account for 49 cases (35.8\%), of which $65.3 \%$ live with single mothers, $18.4 \%$ with single fathers and $14.3 \%$ live with their grandparents. Sixty percent of patients were the first-born child in the family. The majority of the patients were raised in a family with more than one child $(68.6 \%)$. The majority of children have both parents in employment (53.3\%), and parents predominantly had a secondary level education (79.7\%). A large proportion of the single-children have their own bedroom (72.1\%). The questionnaire responses show that $61.3 \%$ of the patients do not read books, and prefer movies for their free time, mainly comedies (64.2\%). The patients' preferred musical styles were differing with $32.1 \%$ preferring hip hop music, while $27.7 \%$ prefer popular forms of folk music.

\section{Discussion}

Alcohol poisonings are a significant health problem due to morbidity, anxiety and pain of the child and their family; such cases increases the burden on the health care system and waste parents' working hours. Children are particularly susceptible to significant alcohol-related damage.$^{[7,11]} \mathrm{Health}$ professionals need to be able to identify adolescents who are experiencing difficulties with alcohol. This problem may come to their attention when an adolescent with acute alcohol intoxication presents to an emergency department. ${ }^{[12]}$

Our study represents the first systematic research of alcohol poisoning among adolescents in Bulgaria. The results show that adolescents usually drank outside their home environment. The most frequent context for intoxication was meeting with friends. The shift of the center of socialization from the family towards peer groups leads to loss of emotional attachment to parents substituted by relationship with a larger number of social group members. Lamminpää reported that motives leading to alcohol intoxication include: a wish to get drunk, experimenting, and problems in human relationships. Most cases of childhood intoxication were attributed to experimentation (49\%). ${ }^{[13]}$
Increasing alcohol consumption leads to an increasing number of acute alcohol poisonings and associated problems. Based on the results of this study, we developed a program for the prevention of alcohol consumption and poisonings among adolescents. This preventative strategy is based on both psychological and social approaches. The proposed preventive program may play an important role in reducing the consequences of alcohol consumption among young people. Such prevention programs should be further developed and popularized among physicians.

\section{Conclusion}

The results of this study indicate that alcohol poisoning among adolescents is an important medical problem. Applying the methods of preventive medicine and clinical toxicology, the research indicates a certain social need for additional knowledge about the extent and character of the phenomena of alcohol use and abuse among adolescents.

\section{Conflict of Interest}

The authors declares no conflict of interest related to this work.

\section{References}

1. Radenkova-Saeva JV, Boyanova AS. Acute ethanol poisoning - epidemiological study in a period of nine years. Clin Toxicology 2010;48:278. [Abstract]

2. Hubenova A, Milcheva V. Acute ethanol poisoning in childhood: clinical and laboratory findings, therapeutic drug monitoring (Abstracts Third International Congress of Therapeutic Drug Monitoring and Clinical Toxicology 129) 1993;15:167.

3. Roncević N, Konstantinidis G, Stevanović V. Acute alcoholic intoxication in children in Vojvodina. [Article in Croatian] Arh Hig Rada Toksikol 1989;40:47-55. [Abstract]

4. Targosz D, Szkolnicka B, Radomska M, Kaczmarczyk A. Drugs of abuse--an analysis based on cases from the Kraków Department of Clinical Toxicology of Jagiellonian University College of Medicine in 1997-2000. Przegl Lek 2001;58:232-6.

5. Lamminpää A, Vilska J. Acute alcohol intoxications in children treated in hospital. Acta Paediatr Scand 1990;79:847-54.

6. Lamminpää A. Alcohol intoxication in childhood and adolescence. Alcohol Alcohol 1995;30:5-12. 
7. Anna Zawadzka-Gralec, Hanna Zielińska-Duda, Mieczysława Czerwionka-Szaflarska, Ewa Węgrzynowska, Danuta Kurylak, Sylwia Siwak, et al. Acute poisoning in children and adolescents. Pediatr Pol 2008;83:373-9.

8. D'amico EJ. Factors that impact adolescents' intentions to utilize alcohol-related prevention services. J Behav Health Serv Res 2005;32:332-40.

9. Reynaud M., Parquet PJ, Largue G. Les pratiques addictives. Usage, usage nocif et dependence aux substances psychoactives. Paris: Odile Jacob; 2000. p. 118-42

10. Botvin GJ, Kantor LW. Preventing alcohol and tobacco use through life skills training. Alcohol Res Health 2000;24:250-7.

11. Bentur Y, Obchinikov ND, Cahana A, Kovler N, Bloom-Krasik A, Lavon O, et al. Pediatric poisonings in Israel: National Poison Center data. Isr Med Assoc J 2010;12:554-9.

12. Woolfenden S, Dossetor D, Williams K. Children and adolescents with acute alcohol intoxication/self-poisoning presenting to the emergency department. Arch Pediatr Adolesc Med 2002;156:345-8.

13. Lamminpää A, Vilska J. Alcohol intoxication and psychosocial problems among children. Acta Psychiatr Scand 1990;81:46871. 